\title{
Ecocide and genocide in the Iraqi Marshlands
}

\author{
J. W. Dellapenna \\ Villanova University, USA
}

\begin{abstract}
The Tigris and the Euphrates cross a largely arid land and empty into the Persian Gulf through the largest natural marshes in southwest Asia. From time immemorial, the marshes were a region in which a community of people made their homes, derived their livelihood, and preserved a particular local culture closely linked to the marshes. As recently as 1990, these marshes constituted healthy, ecologically rich wetlands. After the Marsh Arabs joined in the revolt against Saddam Hussein in 1991, he undertook to drain the marshes in order to bring these highly independent people under his control. The former marshes became barren, salt-encrusted land, with the Marsh Arabs living as refugees in Iran and Iraq. No attempt was made to develop the diverted water or drained lands. The destruction was an ecocide adopted as a means of genocide against the Marsh Arabs. After the fall of Saddam, the Marsh Arabs returned to the land and restored the flow of water by simply breaching the dams, dikes, and canals - with little or no attention to water quality concerns. Today about $50 \%$ of the marshes have been restored. In this paper, I examine the legal issues relating to the destruction and the restoration of the Iraqi marshes.

Keywords: ecocide, genocide, international law, Iraq, occupation law, Ramsar Convention, water law, wetlands.
\end{abstract}

\section{Introduction}

Iraq includes the bulk of what historically was called Mesopotamia-the land between the rivers (the Tigris and the Euphrates). The two rivers cross a largely arid land and have given life to that land through irrigation for more than 5,000 years. The two rivers join about 120 miles north of their discharge into the Persian Gulf to form the Shatt-al-Arab. The marshes began 50 or so miles above the joining of the rivers and once reached all the way to the Gulf. As recently as 1990, these marshes covered about 12,000 square miles, mostly in Iraq, with a 
small area of the marshes in Iran (Nicholson and Clark [19]). In 1990, the marshes constituted healthy, ecologically rich wetlands, teeming with aquatic life, buffalo and other animals adapted to marshes, and migratory birds (Rzóska et al. [20]). Only three years after 1990, most of the marshes were reduced to a barren, salt-encrusted land (al-Bayati [2]; United Nations Environmental Programme [30]).

The Iraqi marshes were the largest area of wetlands in southwest Asia, and one of the largest in the world. To the south and west of the marshes are some of the driest deserts on earth, to the north and northeast are mountains (with more deserts beyond the mountains), and to the southeast is the Persian Gulf. The marshes were important for the ecology of three continents. Given the remoteness of the marshes from other wetlands, the marshes had developed unique species, but the true importance of the wetlands arose not from their isolation but from the connection to other, far distant ecosystems. The marshes were the major breeding ground for many of the species of fish in the Persian Gulf and they were the major stopover on the flyway from northern Eurasia to eastern and central Africa. Numerous bird species that breed in the Artic or subArtic summer and winter in eastern and central Africa face a barrier in their migratory path - the great desert that stretches from the Atlantic across northern Africa, the Middle East, and on into Central Asia, ending in Mongolia. The avian migration routes depended on the availability at suitable distances of wetlands where the birds could find water and food - and no stopover was more important to these migrations than the Iraqi marshes. Without the marshes, there are only a few scattered oases or farmers' fields for the birds. These alternatives, taken together, could not sustain the multitude of birds involved in these transcontinental migrations.

From time immemorial, a large community of people - the Ma'dan (Marsh Arabs) - made their homes in and derived their livelihood from the Marshes (Thesiger [23]). Their way of life was based on agriculture, animal husbandry, hunting, fishing, and the servicing of commercial boats that traversed the Tigris River. Yet the inhabitants of the marshlands have always engendered distrust and suspicion among other Iraqis. The marshes were a refuge for smugglers, political dissidents, and others who sought to escape the constraints of the surrounding society. Such a society was bound to rouse the suspicions of Saddam Hussein, and his wrath should they openly oppose his rule. In 1990, they did just that.

\section{The destruction of the marshes}

The marshes were the scene of the fiercest fighting in the Iran-Iraq War of the 1980s - the longest and bloodiest war in modern Middle Eastern history. This fighting did not harm the marshes much because the Iraqis increased the flow of water into the marshes in order to stop Iranian advances. While plans had been developed for various engineering works in the marshes since the early twentieth century, these projects had never materialized. The wholesale destruction of the marshlands began only in 1992 - after the Marsh Arabs rose in revolt during the Gulf War after the first President Bush called upon Iraqis to overthrow the 
Saddam Hussein regime. Abandoned by the Americans, Saddam easily suppressed the revolt of the Marsh Arabs and other Shiite Arabs in southern Iraq. (The Americans and their allies did not even attempt to prevent the use of Iraqi air power against the Shiite rebels - in contrast to their actions to prevent the use of air power against the Kurds in the north of Iraq.) Within months of the end of the revolt, the Iraqi government undertook to drain the marshes, dredging canals, constructing dams, and leaving about $90 \%$ of the wetlands desiccated.

The destruction of the marshlands served no other purpose than to destroy the cultural and social cohesion of the Marsh Arabs. Iraqi state-owned media preceded the assault on the marshes with a series of articles deriding the Marsh Arabs as primitive "monkey-faced" people, who were not real Iraqis (Fawcett and Turner [11]). Dams and drainage canals were built without any apparent agricultural or developmental purpose. It became impossible for the Marsh Arabs to survive where they were. After 1993, only a few thousand of the perhaps 500,000 Marsh Arabs remained in the region of the former marshes (alShahristani [3]). In 2002, 40,000 Marsh Arabs still lived in refugee camps in Iran. The remainder of the Marsh Arabs was dispersed throughout Iraq.

\section{Ecocide as genocide}

High quality satellite imaging of southern Iraq exists for the last 30 years. The imaging clearly shows that while the marshes had suffered some damage before 1992, the marshes were largely intact as of that date. The satellite images show that the marshes after 1993 no longer existed in any meaningful sense. The only part of the marshes that remained intact were stretches that straddled the IranIraq border and were fed entirely by streams from Iran, representing about $10 \%$ of the original marsh area. Further complicating the situation are the 32 dams on the upper Tigris and Euphrates (Adriansen [1]). These dams have the capacity to store the entire capacity of the two rivers (Dellapenna [9]). Spring floods disappeared because of regulation of the rivers. That by itself caused damage to the marshlands, but not their wholesale destruction.

Destruction of the marshes affected the regional climate. The resulting reduction of evaporation caused a decline in rainfall and increased summer temperatures, making the area even more inhospitable. A further consequence of such massive destruction was the extinction of species of animals and plants that were unique to the marshes. Lacking a thorough baseline survey of the biological resources of the marshes from before their destruction, we have no way of measuring precisely how many species went extinct, but that at least some and perhaps many such species disappeared cannot be seriously doubted. Moreover, because these size and location of the marshes, their destruction had effects far beyond the region itself. While some of the migratory birds flying between Africa and the north of Asia and Europe could find substitute stopovers, there is no wetland of similar size anywhere near the paths of these birds - especially given that most of these alternatives had been developed for urban or agricultural use by substantial human populations. Similar effects fell on the fish that formerly bred in the marshes without living there. Thus, while neither the 
number nor extent of species extinction or of negative impacts on migratory birds or fish that spend most of their life elsewhere can now be documented, clearly these effects were massive.

The scale and effects of the destruction are such that the draining of the marshes is a leading example of "ecocide"- the destruction of an entire ecosystem. Ecocide is not a legal concept. There is no legal definition of the concept; ecocide is not prohibited; there is no prescribed punishment for those responsible. Rather ecocide is a rhetorical term, an ethical judgment, which serves to focus attention on a massive and often irreversible destruction of a significant ecosystem. There are many other examples of ecocide in the twentieth century and earlier (Broswimmer [5]). This hardly makes the practice acceptable, especially when it generates devastating effects over nearly half of the planet.

The ecocide of the Iraqi marshes would violate the terms of the Ramsar Convention, if it applied to the marshes (United Nations [29]). The Ramsar Convention requires participating nations to identify "wetlands of international importance" and to develop and implement plans to preserve those wetlands and their ecosystems. But Iraq never ratified the Ramsar Convention, and therefore is not bound by its terms - unless the Ramsar Convention expresses obligations under customary international law. That proposition, however, is unlikely (Gardner [12]).

A unique feature of the ecocide of the Iraqi marshes set it apart from other instances of ecocide - namely, that the marshes were destroyed for the purpose of destruction and not for some arguably beneficial purpose such as economic development. Ecocide was used as a mechanism for genocide (Dellapenna [7]). The Genocide Convention defines "genocide" as the "deliberate[] inflicting on [a] group conditions of life calculated to bring about its physical destruction in whole or in part" with the intent "to destroy, in whole or in part, a national, ethnic, racial or religious group, as such." (United Nations [26]). The Marsh Arabs are a distinct ethnic group, and as such are subject to the protection of the Convention, which in turn reflects the prohibition of genocide in customary international law. As a result of the engineering works constructed in the area after 1992, the Marsh Arabs saw their economic base and their way of life destroyed, were forced into out-migration, and generally were pauperized. While how many individual Marsh Arabs died as a result of these actions is not clear, clearly the group as a whole was in the process of being destroyed as a group.

The ecocide of the Iraqi marshes also violated several other multilateral conventions, including:

1. The International Covenant on Civil and Political Rights (United Nations [27]), which expresses customary international law (ILA $[15]$, arts. $4,18,19)$ and requires that people be given a voice in decisions affecting their lives;

2. The International Covenant on Economic, Social, and Cultural Rights (United Nations [28]), which has been interpreted by the 
United Nations Human Rights Committee as supporting the

existence of a human right to water and which many people would argue has also become customary international law (ILA [15], art. 17);

3. ILO Convention no. 169 on Indigenous and Tribal Peoples (International Labor Organization [14]), which provides that people following a traditional, pre-industrial lifestyle are not to be denied the resources they need to continue that lifestyle, again arguably a requirement of customary international law (ILA [15], arts. 20, 21);

4. The Espoo Convention on Environmental Impact Assessment in a Transboundary Context (United Nations [25]), which requires that before undertaking any activity that would significantly impact the environment, there must be an environmental impact assessment of the activity and public participation in this process and which many people would argue has also become customary international law (ILA [15], arts. 29 to 31); and

5. The Convention on Biological Diversity (United Nations [24]), which requires that States not undertake activities that will significantly decrease regional or global biological diversity, again arguably an obligation under customary international law (ILA [15], arts. 22 to 25$)$.

\section{The Restoration of the marshlands and the role of law}

For a decade, the Marsh Arabs found that they were largely nobody's friends. Because they were Shiite, there was no great interest on the part of most of the rest of the Arab world, which is mostly of the Sunni persuasion. Because they were Arab as well as the unwillingness to risk reigniting the Iran-Iraq war from the 1980s, there was no great interest in helping the Marsh Arabs on the part of Iran. Iran even arranged to repatriate most of the refugees who arrived in 1992 and 1993 back to Iraq as soon as it was feasible And the rest of the world, cut off from current information about the region by the Iraqi government and without the sort of vivid sound and video bites that would focus attention in the contemporary world, simply remained unaware of the problem.

As soon as the Saddam Hussein regime fell, many of the refugee Marsh Arabs began to return to the marshlands. Western scientists counseled careful study of the desiccated lands to determine what the effects of reflooding would be, given the limited available waters and the often questionable quality of those waters. (Eden Again Project [10]. The returning refugees did not wait for such studies. They simply grabbed shovels and bulldozers and reflooded perhaps $40 \%$ of the 
marshlands within the first year after the fall of Saddam (Jacobson [16]). Today more than $50 \%$ of the marshes have been restored (United Nations Environmental Programme [30]). Western scientists soon found themselves studying the effects of reflooding rather than the possibilities of refloodingeffects that often proved far less alarming than had been predicted (Banat et al. [4]; Harding [13]; Lawlor [17]; Richardson et al. 21]; Richardson and Hussain [22]).

Efforts to restore or improve the lives of the Marsh Arabs did not progress as much as the restoration of the marshes themselves. The Marsh Arabs need education, jobs, healthcare, and more. The region is not without economic resources. A great deal of potential wealth exists there in the form of oil. Certainly the oil wealth needs to be used to meet the needs of all Iraqis and not just of the Marsh Arabs, but some of this money could be used to improve the situation of the marshes and the Marsh Arabs. The United Nations Economic Programme could provide useful capacity building and other initiatives for the benefit of the marshlands. International funds - such as from the Global Environment Fund and other international agencies - could also play a role. These efforts have largely been stymied by the continuing and growing disorder in Iraq.

Looking beyond what has been, and should be, done to restore the marshes and to improve the lives of the Marsh Arabs, law can be used to enhance and protect the restored marshes. First, those responsible for the destruction of the marshes can be tried and punished, if not for ecocide then for genocide and other international crimes. While Saddam Hussein himself is now beyond the reach of another trial, other officials responsible for the destruction of the marshes are in custody and should answer for their actions. Holding such persons accountable will do much to discourage future plans to despoil the Iraqi marshlands.

On a more positive note, the new Iraqi government should participate in international efforts to regulate the future water management problems in the region. At the proper time, the new government should undertake negotiations with Syria and Turkey on the Euphrates River, and with Iran, Syria, and Turkey on the Tigris River (or all four countries could negotiate a treaty covering both rivers and their tributaries) (Dellapenna [9]). While there are a few bilateral treaties governing the use of water from the Tigris and Euphrates rivers, there is no comprehensive regional treaty. To ensure the continuing vitality of the marshlands, such treaties are imperative. The governing principles are summarized in the Berlin Rules on Water Resources: 1) the duty to cooperate; 2) participatory management; 3) conjunctive management; 4) integrated management; 5) equitable utilization; 6) sustainability; and 7) the minimization of environmental harm (ILA [15]).

The new Iraqi government has announced its intention to ratify the Ramsar Convention and to designate the largest of the southern marshes as its first "Ramsar wetland." (Burns et al. [6], art 203). But the government has not yet done so. Even if the Iraqi government were to take these steps, enforcing any implementing regulations will remain impossible so long as the disorder persists. 
Even without awaiting the implementation of the obligations that arise under international law, the Iraqi government should enact a new water law for the nation. A sound new national water law should be based upon the following premises: 1) water is vitally important; 2) water is a public good; 3) water is an ambient resource; 4) water must be conjunctively managed; 5) water management must be integrated with the management of related resources; and 6) water is subject to economic incentives. Some of these premises might appear to be self-evident, but they are all too often overlooked.

The legislature must also choose between characterizing water as common property, as private property, or as public property, and between using public regulation or tradable permits as primary management tools. For reasons that are too complex to develop here, I would argue in favor of a public property/managerial regime over other possible approaches (Dellapenna [8]). Such an approach is also most consistent with the shari'a rules on water (Naff and Dellapenna [18]). Properly designed it will assure participatory, conjunctive, integrated, and sustainable management that will minimize environmental harm arising from the management of the nation's water resources. In fact, a new water law has been under study since shortly after the fall of the Saddam Hussein regime, but the social disorders in the country have resulted in other priorities than the enactment of a new water law. Whether the new law will be based on the proper principles is still uncertain. One can only expect real progress on all of these legal issues after the restoration of order and the solution of the even more pressing problems that bedevil Iraq today.

\section{References}

[1] Adriansen, H.K., What Happened to the Iraqi Marsh Arabs and Their Land? The Myth about the Garden of Eden and the Noble Savage, 2004. Online www.diis.dk/graphics/Publications/WP2004/hka_Iraqi_Marsh Arabs.pdf.

[2] al-Bayati, H., Destruction of the Southern Marshes. Iraq Since the Gulf War: Prospects for Democracy, ed. Fran Hazelton, Zed Books, Ltd.: London, pp. 141-146, 1994.

[3] al-Shahristani, H., Suppression and Survival of Iraqi Shi'is. Iraq Since the Gulf War: Prospects for Democracy, ed. Fran Hazelton, Zed Books, Ltd.: London, pp. 134-140, 1994.

[4] Banat, K.M., Howari, F. M., \& Abdullah, M.B., Minerology and Hydrochemical Characteristics of the Late Marshes and Swamps of Hor Al-Hammar, Southern Iraq, Journal of Arid Environments 65(3), pp. 400416, 2005.

[5] Broswimmer, F.J., Ecocide: A Short History of Mass Extinction of Species. Pluto Press: London, 2001.

[6] Burns, W., et al., International Legal Developments in Review: International Environmental Law, International Lawyer 40(2), pp. 197$216,2006$. 
[7] Dellapenna, J.W., The Campaign against the Marsh Arabs: Ecocide as Genocide, The Jurist, Jan. 31, 2003. Online http://www.jurist.law.pitt.edu/ forum/forumnew92.php,

[8] Dellapenna, J.W, The Importance of Getting Names Right: The Myth of Markets for Water, William and Mary Environmental Law and Policy Review 25(2), pp. 317-377, 2000.

[9] Dellapenna, J.W., The Two Rivers and the Lands between: Mesopotamia and the International Law of Transboundary Waters, BYU Journal of Public Law 10(2), pp. 213-261, 1996.

[10] Eden Again Project, Building a Scientific Basis for Restoration of the Mesopotamian Marshlands, 2003. Online www.iraqfoundation.org/ projects/edenagain/2003/dmay/5_report.html.

[11] Fawcett, J. \& Tanner, V., The Internally Displaced People of Iraq. The Brookings Institution \& the School of Advanced International Studies at Johns Hopkins University: Baltimore, 2002.

[12] Gardner, R.C., Perspectives on Wetlands and Biodiversity: International Law, Iraqi Marshlands, and Incentives for Restoration, Yearbook of the Colorado Journal of International Environmental Law and Policy vol. 2003, pp. 1-18.

[13] Harding, A., Iraq's Marshes Return," The Scientist 20(8), p. 17, Feb. 2007.

[14] International Labor Organization, ILO Convention no. 169 o Indigenous and Tribal Peoples, approved 27 June, 1989, ILO 3(1), 324, reprinted in International Legal Materials 28(6), pp. 1382-1392, 1989.

[15] International Law Association ("ILA"), The Berlin Rules on Water Resources, in Report of the Seventy-First Conference of the International Law Association 335-384 (2004). Online. www.ilahq.org/pdf/Water\%20Resources/Final\%20Report\%202004.pdf.

[16] Jacobson, L., Back to Eden: Restoring the Marshes of Iraq, Washington Post, p. A11, April 28, 2003.

[17] Lawlor, A., Reviving Iraq's Wetlands, Science 307(5713), pp.1186-1189, 2005.

[18] Naff, T., \& Dellapenna, J.W., Can There Be a Confluence: A Comparative Consideration of Western and Islamic Fresh Water Law, Water Policy 4(6), pp. 465-489, 2002.

[19] Nicholson, E. \& Clark, P., eds., The Iraqi Marshlands: A Human and Environmental Study. Politics Publishing in association with the Amar Foundation, London, 2002.

[20] Rzóska, J., Talling, J.F., \& Bannister, K.E., Euphrates and Tigris: Ecology and Destiny. Zed Books, Ltd.: London, 1980.

[21] Richardson, C.J., et al., The Restoration Potential of the Mesopotamian Marshes of Iraq, Science 307(5713), pp. 1307-1311, 2005.

[22] Richardson, C.J., \& Hussain, N.A., Restoring the Garden of Eden: An Ecological Assessment of the Marshes of Iraq, Bioscience 56(6), pp. $477-$ 489, 2003

[23] Thesiger, W., The Marsh Arabs, Dutton Press: New York, NY, 1964. 
[24] United Nations, Convention on Biological Diversity, opened for signature, 5 June 1992, 1760 UNTS 79.

[25] United Nations, Espoo Convention on Environmental Impact Assessment in a Transboundary Context, approved 25 Feb. 1991, 1989 UNTS 309.

[26] United Nations, Genocide Convention, approved 9 December 1948, 78 UNTS 277.

[27] United Nations, International Covenant on Civil and Political Rights, approved 16 December 1966, 999 UNTS 171.

[28] United Nations, International Covenant on Economic, Social, and Cultural Rights, approved 16 Dec. 1966, 993 UNTS 3.

[29] United Nations, Ramsar Convention on Wetlands of International Importance, opened for signature, 2 Feb. 1971, 996 UNTS 245.

[30] United Nations Environmental Programme, Iraqi Marshlands Observation System, 2007. Online http://www.grid.unep.ch/activities/ sustainable/tigris/mmos.php. 